\title{
Familjebildning och \\ försörjning - en jämförelse mellan nyblivna svenska och turkiska föräldrar i ett svenskt välfärdsperspektiv
}

\author{
MONA FRANSÉHN, BIRGITTA JANSSON, \\ TORUN ÖSTERBERG \& MARGARETA BÄCK-WIKLUND
}

\begin{abstract}
Hur ser anpassningen till den svenska tvåförsörjarmodellen ut för nyblivna föräldrar med svenskt respektive turkiskt ursprung? I följande artikel visar vi hur välfärdsinstitutionernas struktur påverkar både familjebildning och föräldraskap beroende på ursprungsland.
\end{abstract}

\section{Introduktion}

Ett av de centrala problemen i den demografiska utvecklingen i Europa under de senaste decennierna är den låga fertiliteten. I många länder föds det helt enkelt för få

Mona Franséhn, fil.dr i socialt arbete.

Birgitta Jansson, fil.lic i ekonomisk historia.

Torun Österberg, ek.dr i nationalekonomi.

Margareta Bäck-Wiklund, professor i socialt arbete.

Samtliga författare arbetar vid institutionen för socialt arbete, Göteborgs universitet. barn. En allt viktigare politisk fråga för det framtida Europa har därför blivit hur män och kvinnor skall kunna förena familjeliv och arbetsliv. Det alltmer omfattande intresset för befolkningsfrågor i Europa har bidragit till ett ökat fokus på de välfärdspolitiska ramarna, dvs. familjepolitiken och de övriga institutionella stöden till barnfamiljer. När det gäller skillnader i fertilitet och familjebildning kan de europeiska länderna grupperas enligt följande; de skandinaviska länderna, Öst- och Centraleuropa, Sydeuropa och Västeuropa. De skandinaviska län- 
derna har under tiden från 1990 och fram till millenniumskiftet haft en relativt hög fertilitet samtidigt som det moderna familjemönstret (dvs. sammanboende istället för äktenskap, hög skilsmässobenägenhet, relativt hög andel ensamstående föräldrar) har varit mer dominant där än i övriga Europa. Desydeuropeiskaländerna har under samma tidsperiod haft den lägsta fertiliteten samtidigt som förändringarna i familjemönstren varit begränsade. Dessa förhållanden presenteras och analyseras i en rapport från Europeiska Rådet, Fertility and new types of households and family formation in Europe, (Pinnelli et al. 2001, chapter 1). I rapporten urskiljs fyra övergripande förhållanden som antas påverka fertiliteten: det institutionella stödet som ges till individer och familjer med barn, dvs. kostnader för och tillgång till barnomsorg, arbetsmarknaden och boendekostnader, graden av modernisering, både materiellt och post-materiellt, dvs. en ökad betydelse av livskvalitet och personlig utveckling snarare än individuell kapitalackumulering, graden av sekulariseringen och slutligen genussystemets utformning bl.a. kvinnors ökade tillgång till och deltagande inom utbildningssystemet, arbetsmarknaden och i politiken. De nedan nämnda förhållandena sammanfattar det som Pinnelli et al. mer allmänt menar med modernisering: education, employment, personal fulfillment, new experiences and excitement, non traditional life courses, parenthood on hold, small families, individual/mental and economic high cost.

Enligt samma källa har Sverige, tillsammans med de övriga skandinaviska länderna, en högre grad av modernisering, bättre villkor för kvinnorna, ett väl utbyggt institutionellt stöd för barnfamiljer samt en högre fertilitet än flertalet av övriga europeiska länder och framstår därigenom som undantaget i Europa. Ett flertal studier framhåller liknande faktorer vid jämförelser mellan länder; Sveriges särställning inom familjeområdet (t.ex. Korpi 2000) och Sverige som ett av världens mest sekulariserade länder (Therborn 2004). Även i undersökningen World Value Survey (www. worldvaluessurvey.org), där man med hjälp av enkäter kartlägger värderingar hos världens befolkning $\mathrm{i}$ en rad avseenden som berör livsstil och framtid, hamnar Sverige enligt Inglehart och Welzel (2005) på en extrem plats. Svensken tänker icke-religiöst, förnuftsstyrt och är inriktad på självförverkligande snarare än överlevnad till skillnad från flertalet andra länder.

I följande artikel avser vi att genom analys av ett registermaterial bestående av kvinnor födda i Sverige respektive Turkiet och som får sitt första barn i Sverige och genom intervjuer utformade som livshistorier med nyblivna föräldrar av svenskt respektive turkiskt ursprung, belysa hur anpassningen till den svenska tvåförsörjarmodellen ser ut. Vi hoppas att genom detta förfaringssätt få en förståelse av vilken betydelse ekonomiska, sociala och kulturella erfarenheter har för unga föräldrars sätt att orientera sig i den sociala världen, här förstått som egna resurser och förväntat stöd av stat och/ eller familj, har för familjebildning och försörjning. Vi är väl medvetna om de problem det innebär att arbeta med olika typer av datamaterial. Men genom att sammanföra ett kvalitativt och ett kvantitativt material, hoppas vi skaffa oss en uppfattning om både 
övergripande mönster med avseende på föräldrablivandet samt om de bevekelsegrunder som blivande föräldrar talar om. Det kvantitativa registermaterialet visar utfallet av kvinnornas handlande - dvs. att bli mor. Det kvalitativa materialet med livshistorier ger främst kunskap om resonemangen inför föräldrablivandet med avseende på tidigare erfarenheter och aktuell situation samt om upplevelsen av att vara förälder (Franséhn \& Bäck-Wiklund 2009).

Ett vanligt sätt $i$ jämförande studier är att välja kontrasterande exempel (Brannen et al. 2002). Föräldrar med svenskt respektive turkiskt ursprung kan antas ha olika dispositioner som påverkar deras handlingar och förhållningssätt såväl till familj, föräldraskap som välfärdsstat. Föräldrar med turkisk bakgrund är också en stor befolkningsgrupp i Sverige. De första turkiska medborgarna anlände i mitten av 1950-talet, då som arbetskraftsinvandring med ca 500 personer årligen. Sammanlagt har 27000 personer invandrat till Sverige under de senaste 20 åren (SCB:s årsböcker). De är således en grupp som är möjlig att beskriva statistiskt och som också har erfarenhet av det svenska välfärdssystemet över tid. Gruppen som helhet har en mer utsatt ekonomisk situation och de har fler barn i genomsnitt än svenskfödda föräldrar.

Artikeln är disponerad på följande sätt. I nästa avsnitt ges en kort beskrivning av den institutionella bakgrundens betydelse för föräldrablivandet. I avsnitt två redovisar vi delresultat från analysen av registermaterialet. Tyngdpunkten i den analysen är vilken betydelse som förankringen på arbetsmarknaden har för första barnets födelse beroende av om kvinnan är född i
Sverige eller i Turkiet. Fokus i artikeln ligger på den kvalitativa studien som presenteras i avsnitt tre och utgår utifrån de nyblivna föräldrarnas livshistorier. Artikeln avslutas med en sammanfattande diskussion.

\section{Staten och familjen}

Intresset för befolkningsfrågor har långa anor i Sverige och har resulterat i en familjepolitik med omfattande stöd till föräldrar i föräldraskapets olika faser. Socialpolitiken och framför allt familjepolitiken i Sverige ser individen som den minsta enheten. Arbetslinjen genomsyrar de flesta socialförsäkringar i Sverige och bygger på inkomstbortfallsprincipen. Det innebär i korthet att det för blivande föräldrar är viktigt att ha en arbetsinkomst innan man får barn för att få en bra ersättning under föräldraledigheten. För nyblivna föräldrar med en svag anknytning till arbetsmarknaden utgår bara garantibeloppet. ${ }^{1}$ Det finns alltså starka incitament att först etablera sig på arbetsmarknaden innan man blir förälder. Detta kan vara en bidragande orsak till att medelåldern för förstföderskor i Sverige har stigit från 24,0 år 1970 till 29,0

1 Den svenska föräldraförsäkringen är konstruerad på följande sätt (år 2008): totalt utgår 480 dagar. Av dessa ersätts 390 dagar enligt inkomstbortfallsprincipen (där ingår två s.k. pappamånader och två s.k. mammamånader vilka inte kan överföras till den andra partnern). Resterande 90 dagar ersätts med garantibeloppet vilket är (år 2008) $180 \mathrm{kr} / \mathrm{dag}$. Har man ingen inkomst ersätts alla dagar med garantibeloppet.

Franséhn, Jansson, Österberg \& Bäck-Wiklund: Familjebildning och försörjning... 
år 2006. ${ }^{2}$ Liknande förändringar finns även i andra europeiska länder och kombinationen barn, arbete och familj måste ses i sitt sammanhang och likartade mönster kan ha olika bakomliggande förklaringar. Kvinnor i Sverige har emellertid svarat på signalerna i familjepolitikens arbetslinje i högre grad även i jämförelse med kvinnor i andra skandinaviska länder som har liknande föräldraförsäkringar (Björklund 2006). För unga kvinnor i Sverige idag förefaller det vara viktigt att först avsluta sin utbildning och att arbeta ett antal år innan man bildar familj (Björklund 2007). Flera andra studier (se Hoem 2000, Andersson 1999, 2000, Bracher \& Santow 1998, 2001, SCB 2002) visar hur ekonomiska förhållanden samverkar med fertiliteten. Sverige har i ett europeiskt perspektiv de största variationerna i födelsetal och dessa följer med viss eftersläpning de ekonomiska konjunkturerna (Fagnani et al. 2004). Sett över ett längre tidsperspektiv har dock svenska kvinnors summerade fruktsamhet minskat något från 2.2 barn per kvinna år 1960 till 1.9 barn år 2007. För kvinnor boende i Turkiet har utvecklingen varit långt mer dramatisk från 6.2 i summerad fruktsamhet 1960 till 2.2 år 2007. ${ }^{3}$ (www.prb.org)

I Esping-Andersens (1999) typologi av

2 Sveriges officiella statistik. Statistiska meddelande BE 12 SM 0701 Folkmängd i hela riket, länen och kommunerna 31 december 2006 s. 6. se även www.scb.se/befolkning

3 SCB - Befolkningsstatistik i sammandrag 1960 - 2007. www.scb.se/templates/tableOrChart_26040.asp för år 1960 och www. prb.org/pdf07/07WPDS_Eng.pdf s. 9 för år 2007. välfärdsregimer betonas bl.a. relationen mellan stat och familj. Sverige framställs som arketypen för den socialdemokratiska välfärdsregimen baserad på tvåförsörjarmodellen. Både man och kvinna förväntas förvärvsarbeta och bidra till familjens försörjning. Det gör att Sverige har en hög grad av de-familisering. I motsats till detta står familisering som grundas på principen om subsidiaritet, vilket innebär att det är familjen och nätverket som i första hand ska ge hjälp och stöd, och att staten kommer in som ett sista stöd. Turkiet kan klassificeras som tillhörande "Medelhavsregimen" med hög grad av familisering. Stödet till föräldrar i föräldraskapets olika faser är starkt begränsat och familj och släkt förväntas ta ett ansvar. ${ }^{4}$ Detta innebär att kvinnor som har sitt ursprung i det svenska eller det turkiska samhället kan förväntas ha olika erfarenheter och föreställningar av familjebildning och föräldraskap.

Graden av modernisering påverkar troligen även synen på kombinationen arbete, föräldraskap och familj. Som beskrevs inledningsvis är Sverige ett land med hög anpassning till och tilltro till den svenska välfärdsstaten i kombination med en långtgående modernisering. Det finns emellertid en föreställning om att modernisering löser upp banden mellan generationerna (Ringen 1987). Nyare forskning visar att det

4 En föräldraförsäkring finns inte utan kvinnor som blir mödrar har rätt till 16 veckors moderskapsersättning (8 veckor innan förlossning och 8 veckor efter) Screening Report Turkey Ch 19 Social policy and employment. ec.europa.eu/ enlargement/pdf/turkey/screening_reports/ screening_report_19_tr_internet_en.pdf 
finns skäl att revidera den föreställningen. Beroendet över generationsgränser för ekonomiskt stöd har försvunnit och ersatts av den svenska välfärdsstaten. Banden mellan generationerna tycks dock bestå och bygger nu på frivillighet och därför är man mer beroende av att ha goda relationer till varandra inom en familj (Fritzell \& Lennartsson 2005, Björnberg \& Latta 2007).

Litteratur om turkiska familjer visar att variationen vad avser förändringar som moderniseringen innebär är avsevärd (Kandiyoti 1995, Bastug 2002, Sümer 2004). Myten om den stora turkiska familjen har vederlagts eftersom den i realiteten sällan rymde fler än två generationer, däremot lever föreställningen om familjens betydelse som en: "culturally unquestioned norm in Turkey that close family members are responsible for each other and even in many cases, for distant kin" (Bastug 2002 p. 208). Att turkiskt ursprung betyder att man har erfarenheter av en stor familj är emellertid inte självklart, däremot lever normen om familjens betydelse som en "verklighet för sig» fortfarande kvar (Sümer 2004). Den turkiska sociologen Sema Erder (2002) har studerat familjer i Turkiet som migrerat från landsbygdsmiljö till urban miljö. Resultaten visar på en stor variation av familjemönster och stödjande nätverk, vilka inte alltid är kopplade till släktband. I samband med migration tycks stöd och nätverk utökas utanför familjekretsen. Studien visar att turkiska familjer har en stor potential till förändring och Erder varnar för en stereotypifiering av turkiskt familje- och kvinnoliv som traditionellt och statiskt (se även Akkent 1995).

I analyser av turkiska förhållanden med avseende på familj ger den turkiska psykologen Kagitcibasi (2002) sin tolkning av modernisering. Hon problematiserar föreställningen om en enkel syn på innebörden av modernisering och hävdar att den innebär att familjebanden samtidigt både försvagas och stärks. De ekonomiska banden försvagas medan de emotionella banden mellan generationer snarare förstärks.

Detta är några skillnader och likheter man kan urskilja i synen på familj i svensk och turkisk kontext. Vi går nu vidare och undersöker graden av anpassning till den svenska familjemodellen här tolkad som en anpassning till tvåförsörjarmodellen.

\section{Arbete först och förälder sen - ett kvantitativt perspektiv}

I detta avsnitt undersöker vi om anpassning till tvåförsörjarmodellen och den svenska välfärdsstaten varierar efter ursprungsland. Har kvinnor födda i Sverige i högre utsträckning rätt "timing" i sitt barnafödande, dvs. har de en starkare koppling till arbetsmarknaden före barnafödandet, än kvinnor födda i Turkiet? Om kvinnor födda i Turkiet har internaliserat den svenska familjepolitiken med dess inriktning på arbetslinjen och tvåförsörjarmodellen kommer vi inte att kunna påvisa några skillnader med avseende på den ökade chansen att få sitt första barn givet arbetsmarknadsförankring mellan kvinnor födda i Sverige och Turkiet.

Följande analys bygger på ett longitudinellt registerdata Swedish Income Panel (SWIP) som sträcker sig från år 1983 till år

Franséhn, Jansson, Österberg \& Bäck-Wiklund: Familjebildning och försörjning... 
2001. ${ }^{5}$ Vi undersöker om det finns några skillnader mellan kvinnor födda i Sverige och kvinnor födda i Turkiet när det gäller konsekvenserna för barnafödande med avseende på deras ekonomiska situation innan det första barnets födelse. ${ }^{6} \mathrm{Vi}$ definierar kvinnor utifrån födelseland och inte medborgarskap. Fokus i analysen är att undersöka i vilken grad benägenheten att få sitt första barn är beroende av om man har eller inte har en arbetsinkomst över en viss nivå året innan barnets födelse och om denna benägenhet skiljer sig åt med avseende på kvinnans födelseland. Genom att undersöka detta kan vi visa graden av anpassning till den svenska

5 SWIP skapades genom att i Registret över Totalbefolkningen (RTB) vid Statistiska Centralbyrån för år 1978 dra ett 1-procentigt sampel av svenskfödda personer, vilket gav en sampelstorlek om ca 77000 personer samt ett 10-procentigt sampel av utrikes födda personer vilket gav en sampelstorlek om ca 60000 personer. Tilläggsurval (10 procentiga) drogs bland personer som invandrat år 1979, 1980, ... till och med år 2001. Storleken av dessa sampel varierar naturligtvis med invandringens storlek och är mellan 3000 och 7000 personer. För år 1999 och framåt har vi tillgång till uppgifter för alla nyanlända invandrare.

6 Vi väljer kvinnor i ålder 20 till 44 år som ännu inte fått sitt första barn. Vi följer dem från 1983 till 2001 men de faller ur panelen när de får sitt första barn. Ålder när de kommer in i panelen variera likaså när de faller ur. Som längst kan vi studera samma kvinna 18 år förutsatt att hon inte får barn under perioden 1983-2001. Vi har valt att starta studien vid åldern 20 år då vi vill att hon ska ha haft en möjlighet att förankra sig på arbetsmarknaden. Vi mäter inkomsten året innan barnets födelse då det är då beslutet tas om en önskad graviditet. föräldraförsäkringen och tvåförsörjarmodellen.

Innan vi redovisar resultaten är det viktigt att betona att vi i denna del av studien enbart studerar kvinnor födda i Sverige eller Turkiet. Vi har inte med gruppen kvinnor födda i Sverige med föräldrar födda i Turkiet, vilka finns med i den kvalitativa delen av studien.

Det har tidigare visats att turkiska invandrare har en svagare förankring på arbetsmarknaden, är lägre utbildade och har sämre hälsa än svenskfödda och även i jämförelse med många andra invandrargrupper (se t.ex. Socialstyrelsen 2000). Hur ser då mönstren ut för dessa två grupper av kvinnor som denna studie avser och kan vi se några skillnader i benägenheten att bli förälder i förhållande till arbetsinkomst över en viss nivå året innan barnets födelse?

I Figur 1 har vi skattat hazardchansen ${ }^{7}$ att en kvinna blir mor givet ett antal förutsättningar (civilstånd, bostadsort på länsnivå, utbildningsnivå,) för olika åldrar, födelseland och varierande arbetsmarknadsförankring. ${ }^{8}$ En hazard anger här den chans en kvinna har att bli mor för första gången. För en kvinna född i Sverige, 27 år, gift, boende i "övriga län", med lång gymnasieutbildning, som har en arbetsmarknadsförankring och ännu inte fått barn är chansen ca

7 Vi skattar så kallade hazardrisker. Då det kan låta konstigt att tala om "risker» när det gäller barnafödande har vi valt att byta ut begreppet "risk" mot "chans» i denna studie.

8 Resultaten kommer ifrån en större studie där även fler invandrargrupper studeras. Utförligare modellskattningar kan fås av författarna på begäran. 
32 procent att hon detta år kommer att bli mor. För en kvinna med liknande egenskaper men född i Turkiet är chansen 30 procent. Här finner vi endast små skillnader mellan kvinnor födda i Sverige och kvinnor födda i Turkiet och kvinnor födda i Sverige har givet en arbetsmarknadsförankring en större chans överlag att bli mödrar än kvinnor födda i Turkiet. Om vi däremot jämför kvinnor med låg arbetsmarknadsförankring (dvs. har en årlig inkomst under två basbelopp) har kvinnor födda i Turkiet en högre chans att bli mödrar oavsett ålder än kvinnor födda i Sverige. Det är här vårt huvudintresse ligger, på skillnaden i effekten av att ha en arbetsmarknadsförankring och att vara utan (eller med låg). I Figur 1 visas differensen i procentenheter $i$ chansen att bli mor givet att man har en arbetsmarknadsförankring eller om man inte har det. Om skillnaden mellan dessa chanser är stor kan vi sluta oss till att en kvinnas benägenhet att skaffa barn är starkt kopplad till hennes arbetsmarknadsförankring. För kvinnor födda i Sverige är denna differens mellan 10-15 procentenheter för de flesta åldrar. Chansen att bli mamma givet att man haft en arbetsinkomst som översteg

\section{Figur I.}

Skattade chanser att bli mamma utifrån hazardmodeller för turkisk födda och svensk födda kvinnor boende iSverige ${ }^{*}$

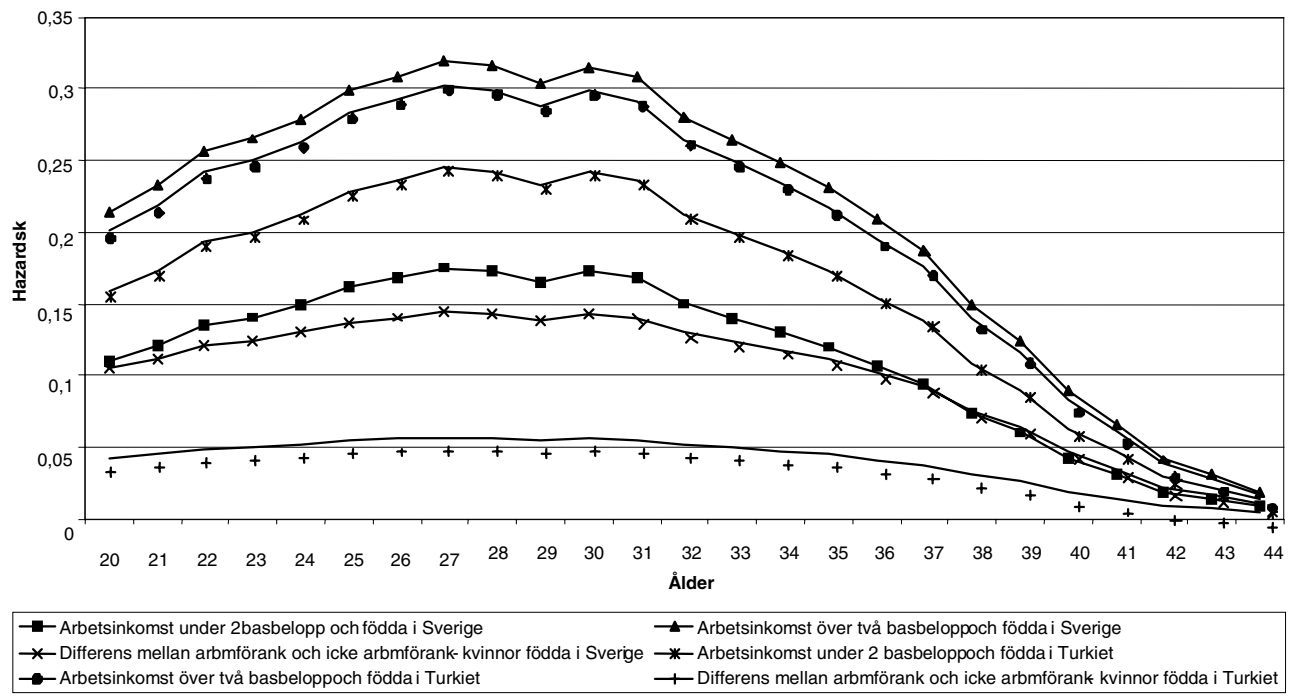

* I modellen har vi skattat chansen att bli mamma givet att personen är gift, bor i »övriga län« har minst en treårig gymnasieutbildning och året är 1990, effekten av arbetsmarknadsförankring (dvs. ha en inkomst som överstiger två basbelopp) är interagerad med ursprung från Turkiet eller svenskt. År 1990 var basbeloppet $29700 \mathrm{kr}$. Vi har valt att redovisa resultat för år 1990 då det är ett år i mitten av vår undersökningsperiod. I modellen har vi kontrollerat för år (genom att använda år-dummies) och finner inga större skillnader mellan åren 1983 och 2001. Kurvorna kan visserligen förskjutas uppåt eller nedåt beroende av vilket år vi väljer men relationen mellan kurvorna förändras inte beroende på valt år.

Franséhn, Jansson, Österberg \& Bäck-Wiklund: Familjebildning och försörjning... 
två basbelopp året innan ökar med 10-15 procentenheter för kvinnor födda i Sverige i jämförelse med om man haft en arbetsinkomst under två basbelopp. För kvinnor födda i Turkiet däremot är differensen liten och ligger kring fem procentenheter, vilket är betydligt lägre än för kvinnor födda i Sverige. Kvinnor födda i Sverige agerar i högre utsträckning än kvinnor födda i Turkiet utifrån den svenska föräldraförsäkringens förutsättningar för att få en bra ekonomisk ersättning under föräldraledigheten.

En slutsats är att kvinnor födda i Turkiet inte svarar på föräldraförsäkringens koppling till arbetslinjen och tvåförsörjarmodellen. Deras föräldrablivande påverkas inte heller lika starkt av om de har en arbetsinkomst eller ej i samma utsträckning som kvinnor födda i Sverige. De tycks därför mindre beroende av välfärdsstaten i sitt handlande kring föräldrablivandet. Låt oss kort se på kvinnor och arbetsmarknad i Sverige respektive Turkiet för att få en uppfattning om förekomsten av vilka olika förväntningar som kvinnorna har erfarenheter av med avseende på försörjning och omsorg.

Figur 2 visar en jämförelse mellan svenska och turkiska kvinnors arbetskraftsdeltagande i respektive land åren 1980 och 2001.

Som figuren ovan visar är det stor skillnad mellan kvinnors arbetskraftsdeltagande i Sverige och Turkiet. Arbetskraftsdeltagande har gått ned något mellan 1980 och 2001 men mest för turkiska kvinnor. År 1980 deltog ca 50 procent av alla turkiska kvinnor i arbete utanför hemmet, år 2001

Figur 2.

Ekonomiskt aktiva kvinnor i Turkiet och Sverige 1980 och 2001.

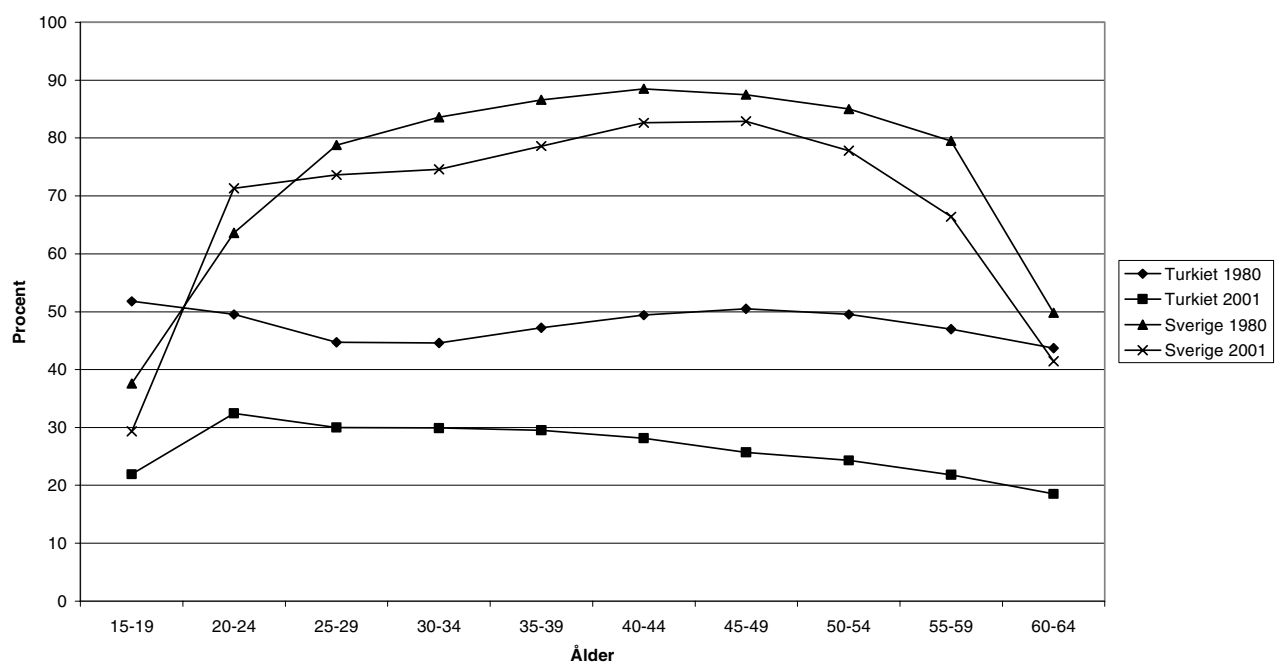

Källa: Statistik från ILO Active population; Tab.1 Total and economically active population by sex and age group. 
hade det minskat till ca 30 procent. Att det har minskat mest för åldersgruppen 15-19 år visar troligen på att turkiska kvinnor i större utsträckning än tidigare studerar. Detsamma gäller för svenska kvinnor. Deras arbete utanför hemmet har också minskat något men befinner sig fortfarande på en internationellt sett mycket hög nivå (över 70 procent).

I denna studie har vi enbart studerat kvinnorna och inte tagit med fädernas eventuella arbetsmarknadsförankring eller födelseland. ${ }^{9}$ Föräldraförsäkringen är en individuell försäkring och vi är endast intresserade av kvinnornas anpassning till normen om arbetsmarknadsförankring före barnafödande. Men troligen så påverkas kvinnornas anpassning till de svenska institutionella förhållandena av om man lever med en man född i Sverige eller i Turkiet. När vi studerar SWIP med avseende på blandade äktenskap finner vi att det är

9 I studien använder vi inte information om barnets far. För sammanboende par finns inte information om fadern förrän en tid efter första barnets födelse och vi undersöker tiden innan barnet föddes. Om föräldraparet är gifta innan barnets födelse kan vi finna information om fäderna men under den tidsperiod (1983 - 2001) vi studerar är sammanboende nästan lika vanligt som äktenskap; därför har vi valt att enbart fokusera på kvinnorna. Andelen äktenskap före första barnets födelse varierar också kraftigt efter ursprungsland och vi undersökte i huvudsak kvinnornas egen arbetsmarknadsförankring då socialförsäkringarna i Sverige bygger på individuella prestationer. Men man bör vara medveten om att äktenskap mellan individer med olika födelseländer varierar. relativt ovanligt när det gäller Sverige och Turkiet. De allra flesta svenskfödda, nästan 90 procent av både män och kvinnor, är sambeskattade med någon som är född $\mathrm{i}$ Sverige ${ }^{10}$ För personer födda i Turkiet är 75 procent av männen och 85 procent av kvinnorna sambeskattad med någon som också är född i Turkiet. För turkiska män är det ungefär dubbelt så vanligt att vara sambeskattad med en svenskfödd 14 procent, gentemot 7 procent för kvinnor.

Att bilda familj och bli förälder handlar ytterst om barnen och deras levnadsvillkor. Resultaten av registerstudien visar tydliga skillnader mellan kvinnor födda i Sverige och Turkiet när det gäller anpassningen till tvåförsörjarmodellen och en bristande förankring på arbetsmarknaden. Det får konsekvenser inte enbart för kvinnan utan även för barnet som föds, eftersom kompensationen i föräldraförsäkringen är mycket låg om det saknas en arbetsinkomst. Detta kan innebära att barn som föds i en turkisk familj har en större risk att leva under knappa ekonomiska villkor än ett barn fött av en kvinna född i Sverige.

\section{En jämförelse av familjebildning mellan svenska och turkiska föräldrar}

I följande avsnitt som bygger på intervjustudiens livshistorier analyserar vi nyblivna föräldrar med olika ekonomisk, social och kulturell bakgrund avseende föreställ-

\footnotetext{
10 Att vara sambeskattad med någon innebär att man är gift eller har ett eller flera gemensamma barn.
} 
ningar om familj, familjebildning och statens betydelse. Vårt syfte är att försöka finna skillnader och likheter i handlande och värderingar som rör familjebildandet mot bakgrund av den svenska välfärdsstaten. Vad händer när föreställningarna om familjeansvar överförs och återskapas till den svenska välfärdskontexten med staten som överordnad garant för stöd och trygghet med den svenska modellen med tvåförsörjare?

Intervjuerna har fokus på den nuvarande livssituationen som de nyblivna föräldrarna har i relation till arbete och föräldraskap. Utifrån ett livshistoriskt perspektiv berättar föräldrarna om sin uppväxt, sin kulturella bakgrund och vilken funktion deras ursprungsfamilj har idag samt hur de resonerat inför beslutet att bli föräldrar. Intervjuerna har genomförts med sammanlagt 28 nyblivna föräldrar i åldern 19 till 43 år med ett barn mellan 6-18 månader. Föräldrarna kan indelas i tre grupper; nyblivna föräldrar med föräldrar födda i Sverige, nyblivna föräldrar med föräldrar födda i Turkiet och en blandad grupp där en av parterna har föräldrar födda i Sverige och den andre har föräldrar födda i Turkiet. I den turkiska gruppen är några av de intervjuade födda i Sverige medan andra är födda i Turkiet och nyligen har kommit till Sverige efter giftermål. ${ }^{11}$

Urvalet inkluderar en variation av föräldrar från varje grupp i syfte att ge en så bred beskrivning som möjligt av olika preferenser och livsstilar. I gruppen där båda föräldrarna är svenskfödda har 16 föräld-

11 Muazzez Gürbüzer, BSc in Social Work, har genomfört nio intervjuer med turkiska föräldrar. rar intervjuats, dvs. föräldrar till åtta barn. Huvuddelen av dessa är i 30-årsåldern (det yngsta paret är 19 och 22, den äldste fadern är 39). De bor både i storstadsmiljö och på landsbygden. De erbjöds att delta i studien via information från Barnavårdscentralen. Föräldrarna intervjuades var för sig. Huvuddelen av intervjuerna har skett i den egna bostaden.

Därutöver har nio föräldrar med turkiskt ursprung (dvs. antingen födda i Turkiet eller i Sverige av föräldrar födda i Turkiet) samt tre nyblivna föräldrar födda i Sverige som sammanlever med partners födda i Turkiet deltagit i studien. Här varierar åldern från 22 till 43 år. Två av de turkiska paren är väletablerade i Sverige med goda anställningar och kan betraktas som något äldre föräldrar (mellan 35-43 år). Ett par består av en 25-årig studerande kvinna och en arbetslös, nyligen anländ, 27-årig man. De bor alla i storstadsmiljö men i olika stadsdelar. I den blandade, svensk/turkiska, gruppen finns sex föräldrar vars ålder varierar från 22 till 41 år. Det är två par och två separata föräldrar som intervjuats (vi har av olika anledningar inte lyckades intervjua den andre parten). Kontakten med föräldrar av turkiskt ursprung har etablerats med hjälp av en medarbetare som själv har turkiskt ursprung.

Majoriteten av föräldrarna kan definieras som medelklass även om vissa har arbetarbakgrund. Huvuddelen (ca 60 procent) är gifta, övriga sammanbor. Utbildningsnivån är relativt hög och föräldrarna har med få undantag någon form av utbildning efter gymnasiet. Vid intervjutillfället var fem av de 28 föräldrarna utan arbete. Två av dessa var studenter som kommer att 
fortsätta sina studier direkt efter föräldraledigheten. Två har sagt upp sina arbeten på annan ort i samband med flyttning och räknar med att få arbeten igen inom kort. Endast en person, en ung svensk pappa, har varit arbetslös under flera års tid. Föräldrarna har mestadels anställningar inom privat eller offentlig sektor, någon enstaka bedriver egen verksamhet.

\section{Livshistoriernas betydelse}

Utifrån individernas livshistorier framträder den egna bakgrunden, de personliga valen och värderingarna i analysen (Brannen et al. 2002). De ger fyllig information om individernas kulturella, sociala och ekonomiska bakgrund och erfarenheter. Det blir därigenom tydligt att kärnfamiljen som ideal har en stark ställning oberoende av i vilket land man är född, samt att relationerna till den egna ursprungsfamiljen är av stor betydelse. Det finns emellertid skillnader i talet om autonomi och beroende. Det handlar om såväl hjälp och stöd genom konkreta handlingar som emotionellt. Inte oväntat betonar flertalet av de svenska föräldrarna sitt oberoende, man talar inte om hjälp och stöd utan om vikten av att bygga starka relationer över generationsgränser. En svensk mamma uttrycker det på följande sätt:

Framför allt är de mera intresserade av att träffa oss, att umgås med oss. Och har vi inte träffat dem på ett par veckor så bestämmer de att nu kommer vi hem till er eller så bjuder de hem oss. Förut kunde det gå ett tag även om man hördes på telefon. Men det är mera viktigt att träffas nu när vi har barn.
De turkiska föräldrarna omhuldar i sitt tal familjens betydelse och de förväntar sig att de egna föräldrarna skall finnas med i deras liv för hjälp och stöd. Flera av de turkiska föräldrarna hänvisar till regler och värderingar som styr och vägleder dem i olika sammanhang, t.ex. vad gäller äktenskap, religion, moderskap och faderskap. Även i Sverige är det vanligt att turkiska ungdomar bor kvar i hemmet tills de gifter sig, vilket innebär att föräldrarna har stort inflytande över deras liv i frågor som rör val av utbildning och lämpliga partners (för äktenskap). Men verkligheten i Sverige överensstämmer inte alltid med det familjeideal som man ger uttryck för. Det illustreras tydligt av två av de turkiska föräldrarna som har få nära släktingar i Sverige. En turkisk mamma uttrycker sin besvikelse över det uteblivna stödet från släkt och familj:

Jag var väldigt ensam under förlossningen... De släktingar som kom och hälsade på besökte mig en kort stund och lämnade mig sedan ensam. De stannade inte kvar för att hjälpa till såsom man brukar göra $i$ Turkiet. Jag ville så gärna ha hjälp av släktingar men det var ingen som kunde ställa upp, alla hade sitt, det var jag lite besviken över.

Några av de turkiska föräldrarna uttrycker i sina livshistorier motsägelser utifrån olika värderingar och traditioner. De är influerade av de turkiska familjetraditionerna men har samtidigt integrerat delar av det svenska samhällets övergripande värderingar. Samtliga turkiska mödrar är medvetna om att jämställdhet är befäst i svensk praxis och lagstiftning (se t.ex. Hirdman

Franséhn, Jansson, Österberg \& Bäck-Wiklund: Familjebildning och försörjning... 
1990, Klint 2002) och de önskar att fäderna skall dela föräldraledigheten med dem i högre utsträckning, då de har planer på att fortsätta arbeta utanför hemmet även i framtiden. De lever med dubbla perspektiv som innebär att de både accepterar och inte accepterar den manliga dominansen (se Kandiyoti 1995). En turkisk kvinna beskriver sin ambivalens på följande sätt:

Jag är inte nöjd med att jag tar så mycket ansvar. Jag skulle vilja dela rakt av men för honom är det inte så. Han har sett att det är ganska normalt att mannen utför lite arbete hemma. Han är uppfostrad så i sin familj så för honom är den bilden sann.

Männen ger också exempel på ambivalens i sina livshistorier. De ser fördelar med det svenska välfärdssystemet och möjligheten till föräldraledighet. Men familjetraditioner och upplevda förväntningar på mannen som familjeförsörjare är starka. En turkisk man, med begränsad erfarenhet av den svenska välfärdsstaten reflekterar över sitt faderskap på följande sätt:

Jag hade inga förväntningar på mig för jag visste inte så mycket. Man tror att pappor inte kan vara så närvarande. Men den närheten som mamman har kan också pappan ha. Jag tror att det är stor skillnad mellan mig och min far. Jag tror inte att min far skulle byta blöjor och tvätta henne men det gör jag. Det är inget problem för mig.

De svensk/turkiska paren har mer av förhandlingar och konflikter när de försöker balansera olika krav och förväntningar. Innan de blev föräldrar var deras olika bak- grunder och erfarenheter sällan problematiskt. Men efter att de blivit föräldrar så uppstår allt oftare diskussioner som rör religion, dop, namngivning och uppfostran. För denna grupp samexisterar manlig dominans med en svensk jämställdhetsideologi. Ofta försöker de göra alla nöjda och ger t.ex. barnet både ett svenskt och ett turkiskt namn. De är medvetna om att deras respektive föräldrar bara vill barnets bästa och de försöker hitta handlingsstrategier för att hantera de olika förväntningarna som riktas mot dem. Att forma föräldraskapet framstår som ett område där nya eller alternativa livsstilar formas. En ung svensk mamma (23 år) gör följande analys av olikheterna:

I Turkiet är de mer vana vid att lägga sig i. Där har man familien och släkten, vi har varit där varje sommar sedan vi blev tillsammans. Där är det mera så att man lägger sig i för att man bryr sig om varandra. Här lägger man sig inte i för att man bryr sig om varandra. Det är en stor skillnad.

Även i frågor som rör arbete, ekonomi och boende uppvisar livshistorierna vissa skillnader. Majoriteten av de svenska föräldrarna är välutbildade och har med några undantag anställning, främst inom privat sektor. Huvuddelen av föräldraparen är också nöjda med den ekonomiska situationen. De uttrycker att de inte har behov av ekonomiskt stöd vare sig från staten eller från de egna föräldrarna, och de betonar även här vikten av oberoende. Om de skulle hamna i en situation där de behöver ekonomisk förstärkning, räknar majorite- 
ten med att de kan få hjälp av sina föräldrar eller från banken. Samtliga föräldrapar med ett undantag har en ekonomisk buffert för oväntade kostnader.

I den turkiska föräldragruppen finns stor variation av ekonomiska villkor och yrken med akademiker, egna företagare och arbetslösa. För höginkomsttagarna är inte ekonomin något problem men vi har också ett par med en utsatt situation. Mannen har nyligen anlänt till Sverige efter bröllopet i Turkiet och söker nu arbete. Deras situation illustrerar hur familjestöd och önskan om oberoende kan skapa en obalanserad och konfliktfylld tillvaro. Hennes familj ger mycket stöd, både praktiskt och ekonomiskt, men samtidigt upplever den nyblivna modern sin egen mor som alltför dominant. Hon lägger sig ofta i hur dottern bör handla i olika situationer. Den nyblivna modern inser nu att föräldraförsäkringen är viktig och att det i framtiden kommer att behövas två inkomster:

Man skall kunna vara hemma så visst är föräldraförsäkringen viktig. Nästa gång jag skaffar barn så skall jag se till att jag inte lever knapert och vet hur mycket jag fär, att vi har stabila inkomster och bättre ekonomi. Jag kommer då att kunna stanna hemma längre om ekonomin tilläter... En inkomst går inte att leva på, det förväntas att bägge skall jobba.

En intressant skillnad i sättet att se på vem som är familjens huvudförsörjare illustreras av de turkiska föräldraparen, där båda har högre utbildning, bra anställningar och likartad inkomst. Trots det betraktas mannen av båda parter som familjens huvudförsör- jare. Kvinnans förvärvsarbete ses som frivilligt, då de båda anser att hon har möjlighet att stanna hemma om hon så önskar. Samtidigt markerar kvinnorna att deras inkomst också är viktig, så det finns en dubbelhet i resonemanget. Trots denna ambivalens visar synsättet att de traditionella värderingarna, i motsats till den svenska tvåförsörjarmodellen, fortfarande är starka och indikerar att mannen skall ha ansvaret för familjen. Männen betonar också kvinnans känslomässiga relation till barnet som ett viktigt skäl att kvinnan skall vara hemma med barnet.

Ett annat förhållande som i hög grad påverkar beslutet om familjebildningen för svenska föräldrar är familjens boendesituation. Flera av dem ser det som en självklarhet att flytta till ett eget hus när man planerar för att få barn. Ett exempel ges här av en 30-årig kvinna som flyttade från lägenhet till hus och inom några veckor efter flytten var hon gravid:

Vi hade pratat om att skaffa barn. Och när vi bodde i lägenheten och jag hade missat att ta P-pillren, så pratade vi mera om det då. Och kom fram till att det inte var något bra tillfälle så jag köpte akutpiller. Men när vi flyttade till huset hade vi tänkt att vänta lite till men så hör man ju ...att det är inte helt lätt att bli med barn. Så då sa vi att varför väntar vi, det kanske tar sin tid ändå. Men det gjorde det inte. ... Men nu när vi bodde $i$ huset kändes det som att vi hade alla förutsättningar som jag ville ha för att skaffa barn.

De turkiska föräldrarna har olika former av boende och planer på ett eget hus har inte

Franséhn, Jansson, Österberg \& Bäck-Wiklund: Familjebildning och försörjning... 
lika starkt fäste här som bland de svenska föräldrarna. Däremot är det viktigt att efter giftermålet få stöd i att bygga upp ett eget hem. Deras situation kan också förstås utifrån att det hos flera finns en tanke om att lämna Sverige och återvända till Turkiet.

Inom den blandade gruppen finns föräldrar med olika livssituationer. En högutbildad svensk man blev utbränd och sjukskriven under en längre period. Efter detta bytte han bransch och har nu istället ett relativt okvalificerat arbete men trivs bra. Familjen bor i en hyresrätt men har planer på att i framtiden flytta till ett annat område, och helst till eget hus. En av mödrarna är student och familjen bor i en mindre bostadsrätt centralt. Hennes turkiska partner (de är inte gifta utan sammanboende) är uppväxt i Sverige och de kommer förmodligen att behålla lägenheten ännu en tid, då de har omvärderat den generella bilden av familjebildningen:

Vi bor fortfarande kvar i en tvåa. Kanske hade vi en föreställning om att när man fär barn så ska man ha allt det där praktiska. En stor lägenhet eller hus och bil och det ena och det andra. Men allt eftersom har vi mer och mer förstått att det är nog samhällets krav, det är inte föräldrarnas.

Det är tydligt att det finns både likheter och skillnader mellan föräldrarna i de tre gruppernas syn på föräldraskap i relation till arbete, boende och ekonomi. En viktig skillnad tycks vara att både svenska och svensk/turkiska föräldrapar ser på framtiden utifrån ett perspektiv där båda parter förvärvsarbetar och delar på ansvaret för barnet. De turkiska föräldraparen ser fadern som den framtida huvudförsörjaren men samtidigt utesluter inte detta synsätt en yrkeskarriär för modern. Kanske innebär utvecklingen av ett blandat synsätt innehållande inslag av både de-familisering och familisering, en förändringsprocess som främjar anpassningen till välfärdsstaten?

\section{Att bilda familj}

De svenska föräldrarna ser familjebildningen som ett individuellt livsprojekt, som tillsammans med partnern utvecklas till ett gemensamt familjeprojekt. Det moderna familjelivet utmärks ofta av en spänning mellan det individuella och det gemensamma projektet vilket medför att förhandlingar och reflektioner är ständiga inslag för att få vardagslivet att fungera (BäckWiklund \& Bergsten 1997). Ursprungsfamiljerna är i våra exempel sällan eller aldrig involverade i planerna på familjebildning. De finns i bakgrunden och förväntas ge stöd om behov uppstår. I förhållande till den äldre generationen uttalas inte några specifika förväntningar utan oftast handlar det om tillfällig barnvaktshjälp etc. Vi finner i likhet med tendenserna i nyare forskning att det i Sverige idag är vanligt förkommande med stöd mellan generationer, både materiellt och socialt stöd (Fritzell \& Lennartsson 2005, Björnberg \& Latta 2007). Det nämns emellertid sällan av de nyblivna föräldrarna när de reflekterar över föräldrablivandet. Istället betonas vikten av oberoende och goda relationer till de egna föräldrarna.

Tidpunkten för att bilda familj kan för de 
svenska föräldrarna ses som ett uttryck för bra "timing". Det innebär att båda parter har hunnit genomföra sin utbildning, fått anställning och har en god boendesituation (jmf Björklund 2006). Det är uppenbart att föräldrablivandet är ett aktivt beslut. Några av mödrarna nämner även den biologiska klockan som ytterligare ett skäl att skaffa barn. Både män och kvinnor lyfter fram att det uppstår en mer generell längtan efter barn i ett visst skede i livet, att det är en naturlig önskan, men för några har det rationella planerandet fått stå tillbaka i en osäker ekonomisk situation:

Om man måste invänta den perfekta situationen så kommer det aldrig att bli möjligt att fatta det beslutet

De svenska föräldrarna ser föräldraförsäkringen som viktig men anser inte att den har haft någon direkt påverkan på deras val att bilda familj. De flesta medger att de inte kände till vilka regler som gällde innan graviditeten. Men samtliga var medvetna om att systemet existerade och att de hade rätt till ersättning för inkomstbortfallet under föräldraledigheten. Av deras resonemang framgår det tydligt att de litade på det svenska välfärdssystemet utan att känna till exakt hur det fungerade. Det tycks som om trygghetskänslan har internaliserats i deras sätt att förhålla sig till livet med tillit till framtiden, att den utgör en del av deras sociala, ekonomiska och kulturella kapital.

För de turkiska föräldraparen är familjebildningen mer av ett kollektivt projekt som relateras till kultur och familjetraditioner i Turkiet. Det diskuteras inom en större familjekrets och är ofta förknippat med giftermål och barn. De egna föräldrarna är mestadels mer involverade i jämförelse med de svenska föräldrarna. Man förväntar sig att dessa skall ta ett större ansvar att stödja den nya familjen, både materiellt och med praktisk hjälp i vardagslivet. Det sätt som de turkiska föräldrarna talar om familjerelationer och förväntningar på stöd reser en del frågor kring anpassning, attityder, och förväntningar som riktas mot välfärdsstatens institutioner. De är generellt sett medvetna om den svenska föräldraförsäkringen men anser inte att denna har påverkat deras beslut att skaffa barn, i detta avseende finns likheter med de svenska föräldrarna. Emellertid förväntar sig de turkiska föräldraparen konkret stöd från sin familj och sina släktingar, något som här illustreras av en turkisk mamma:

Våra föräldrar hjälpte oss med bröllop och bjudningar, sedan fick vi pengar att köpa möbler för. Och mina föräldrar köpte våra mattor men min svärmor var nog den som hjälpte till ännu mera. Sedan hade vi ocksà sparade pengar som vi tog från. För mig är det viktigt att våra föräldrar är delaktiga, både fysiskt och ekonomiskt.

Flera av de turkiska föräldrarna betonar också att det inte är nödvändigt att ha allting ordnat innan man blir föräldrar. I förhållande till de svenska föräldrarna framträder deras annorlunda förhållningssätt tydligt och de kopplar inte ihop de ekonomiska villkoren med viljan och villkoren att skaffa barn. Samtidigt förlitar de sig betydligt mer på ekonomiskt stöd från de egna föräldrarna i jämförelse med den svenska

Franséhn, Jansson, Österberg \& Bäck-Wiklund: Familjebildning och försörjning... 
gruppen. Det är familj och släkt och inte välfärdsstaten som skall ge dem det huvudsakliga stöd de behöver. Här synliggörs det dominerande synsättet som kan hänföras till Esping-Andersens (1999) begrepp familisering och som visar på en grundläggande skillnad som rör erfarenheter och förhållningssätt $i$ jämförelse med den svenska gruppen vad gäller synen på trygghet och konkret stöd.

Den svensk/turkiska föräldragruppen illustrerar i viss utsträckning alla de tidigare resonemangen och synsätten. Deras skäl för familjebildning är mestadels desamma som för den svenska gruppen men inkluderar mera av förhandlingar och konflikter, när det handlar om att balansera de olika bilderna av familjelivet. Den turkiska parten är ofta mer "svensk» i sitt resonemang jämfört med de turkiska föräldraparen. I många fall är de uppväxta i Sverige och deras ursprungsfamiljer har tillägnat sig mer av en svensk livsstil. En turkisk kvinna, gift med en svensk man, beskriver sin situation på följande sätt:

... min familj är inte religiös. De har varit måna om att vi skall växa upp och smälta in $i$ det svenska samhället. Vi bodde $i$ ett villaområde med inte så mycket invandrare... Vi fick göra som de svenska barnen, åka på klassresor, ha det fritt, ha pojkvänner osv.

Ett annat svensk/turkiskt par hade inledningsvis problem i relationen till hennes familj. Kvinnan är född i Sverige av turkiska föräldrar men har under en period bott hos släktingar i Turkiet. Hennes familj var motståndare till att hon gifte sig med en svensk man vilket fick till följd att fadern vägrade komma på bröllopet:

För mina föräldrar var det katastrof, de ville inte ha honom för att han var svensk och att det skulle föra med sig massa problem. Jag vet inte riktigt vad de var rädda för egentligen,... jo jag tror att det var att de sade att svenskar skiljer sig så ofta och att svenskar inte ser så allvarligt på förhållanden, det var nog det de var rädda för.

Den blandade gruppen representerar således föreställningar som finns både i Sverige och i Turkiet men också många motstridiga uppfattningar. De måste handskas med förväntningar och traditioner från två olika system och utvecklar därför olika strategier för att klara av att hantera detta. De är mycket medvetna om de dubbla perspektiven. Det finns en viss ambivalens men oftast tycks de vara förstående och stödjande mot varandra och försöker acceptera de olika förväntningar som riktas mot dem från olika håll.

Analysen visar att det finns både likheter och skillnader mellan föräldrar med avseende på att bli och att vara förälder. Alla omfattar kärnfamiljen som ideal, den positiva synen på föräldraskapet och vikten av utbildning och anställning för att klara av familjebildning. Dock uppvisar varje individuell livshistoria motsägelser, främst är detta synligt bland föräldrarna i de turkiska och blandade grupperna. Oavsett bakgrund tycks emellertid reflexivitet och förhandlingar karaktärisera föräldraskapet, och traditionella familjemönster existerar ofta i samklang med det svenska jämställdhetsidealet avseende kön och föräldraskap. 


\section{Avslutande diskussion}

I denna artikel har vi undersökt om kvinnor födda i Turkiet respektive Sverige, som blir mödrar för första gången, har anpassat sig till den svenska familjemodellen med två försörjare. Analysen sker mot bakgrund av den svenska välfärdsstaten som en jämförelse mellan föräldrar med olika erfarenheter ekonomiskt, socialt och kulturellt. Det blir genom de två datamaterialen tydligt hur unga föräldrar orienterar sitt handlande och resonemang inför föräldrablivandet.

I den kvantitativa studiens resultat framkommer att kvinnor födda i Turkiet inte agerar på samma sätt som kvinnor födda i Sverige när det gäller kopplingen mellan första barnets födelse och arbetsmarknadsförankring.De turkiskakvinnornasföräldrablivande påverkas inte heller lika mycket av om de har en arbetsinkomst eller ej som för de svenskfödda kvinnorna. Detta kan tolkas som en indikation på att preferenser kring familjebildandet i Turkiet spelar roll när det kommer till beslut som att bilda familj även i Sverige.

Utifrån den kvalitativa studien finner vi att de svenska föräldraparen lever i en kontext där välfärdsstaten ger dem en basal trygghetskänsla för föräldraskapet. De har anpassat sig till tvåförsörjarmodellen med individuell arbetsmarknadsanknytning och de strävar efter rätt "timing" för att bli föräldrar. Välfärdsinstitutionernas struktur påverkar både familjebildning och föräldraskap och gör individerna beroende av välfärdsstaten men oberoende av de egna föräldrarna. De har ett annorlunda förhållningssätt till de egna föräldrarna i jämfö- relse med de turkiska föräldrarna. Att bilda familj är ett individuellt projekt för svenska föräldrar och de betonar i högre grad faderns betydelse för omsorgen i familjen. De försöker också i större utsträckning dela ansvaret för hushållsarbete även om detta ibland tycks vara mer av en intention än en faktisk verklighet. Den samstämmighet i talet kring familjebildning som framträder hos de svenska paren kan närmast ses som en gemensam diskurs där vikten av utbildning/arbete, bostadssituation och oberoende ingår som viktiga komponenter.

För de turkiska föräldraparen är familjebildning mer av ett kollektivt projekt som relateras till familjeideal. Trots att de i vissa fall har levt i Sverige under lång tid har de fortfarande ett familjeperspektiv med förväntningar om stöd från familj och släkt, och endast $\mathrm{i}$ undantagsfall talas om rätt "timing". Det svenska välfärdssystemet betraktas som ett komplement till familjestödet. Fastän flera av de turkiska föräldrarna i praktiken har få stödjande släktingar i Sverige, lever de med en retorik där familjen framhålls som den främsta stöttepelaren. Det är också stor skillnad mellan deras generella förväntningar och deras faktiska livssituation. Anpassningen till tvåförsörjarfamiljen är inte lika lätt att urskilja bland turkiska föräldrar som bland de svenska. Fadern ses som huvudförsörjare även i de fall där hustrun har ett bra arbete med motsvarande lön. Viss ambivalens går att spåra när det gäller synen på den traditionella könsarbetsdelningen, hos både män och kvinnor. När familjerna har bott i Sverige under lång tid tycks de leva med dubbla uppsättningar av attityder och värderingar. En likartad situation kan enligt Sümer (2004) uppstå i Turkiet där det »starka tur-

Franséhn, Jansson, Österberg \& Bäck-Wiklund: Familjebildning och försörjning... 
kiska familjeidealet» utmanas av trender på arbetsmarknaden som kräver individualisering, oberoende och rörlighet. I Turkiet är det underförstått att kvinnorna förväntas ta ansvar för omsorg om barn och äldre när kraven från den offentliga och den privata sfären kolliderar. I Sverige tvingas de använda en kombination av kommunal service och familjestöd för att få tillvaron att gå ihop.

Den blandade gruppen har, inte så förvånande, föreställningar som existerar både hos svenska och turkiska föräldrapar. De har problem att klara av förväntningar från två olika värdesystem men är samtidigt skickliga på att utveckla strategier för att hantera dessa skillnader. Genom diskussion och för- handling tycks de hitta lösningar som båda parter accepterar. De har ofta betydande likheter med de svenska föräldrarna i sitt sätt att beskriva vardagslivet. Både stödet från välfärdsstaten liksom tvåförsörjarsystemet tas för givet bland de svenska föräldrarna. För de turkiska föräldrarna är dessa frågor fortfarande under förhandling i den pågående process där de måste förhålla sig till de svenska välfärdsinstitutionerna.

Det tar tid att anpassa sig till ändrade sociala preferenser och normer. Genom att beakta dessa skillnader får vi en ökad förståelse av olika bakgrunder för varje individuellt val.

\section{Referenser}

Akkent, Meral (1995) "A necessary Correction». I Sirin Tekeli (ed.) Women in Modern Turkish Society. London: Zed Books Ltd.

Andersson, Gunnar (1999) „Childbearing Trends in Sweden 1961 - 1997«. European Journal of Population no 15, pp. 1-24.

Andersson, Gunnar (2000) „The Impact of LabourForce Participation on Childbearing Behaviour: Pro-Cyclical Fertility in Sweden during the 1980s and 1990s."European Journal of Population, No 16, pp. 293-333.

Bastug, Sharon (2002) "Household and family in Contemporary Turkey: A historical Perspective«. I Rita Liljeström \& Elisabeth Özdalga (eds.) Autonomy and Dependence in the Family. Swedish Research Institute in Istanbul, Transactions Vol.11.

Beskrivning av Sveriges befolkning, SOS 2005.

Björnberg, Ulla \& Latta, Mia (2007) »The roles of the family and the welfare state. The relationship between public and private financial support in Sweden«. Current Sociology May 2007, pp. 415-445.
Björklund, Anders (2007) "Does family-friendly policy raise fertility levels?" Swedish Institute for European Policy Studies SIEPS report no 3, (2007:3) available at www.sieps.se

Björklund, Anders (2006) "Does family policy affect fertility? Lesson from Sweden". Journal of Population Economics 19, pp. 3-24.

Bracher, Michael \& Santow, Gigi (1998) „Economic Independence and Union Formation in Sweden". Population Studies vol. 52, no. 3, pp. 275-294.

Bracher, Michael \& Santow, Gigi (2001), "Deferment of the First Birth and Fluctuating Fertility in Sweden«. European Journal of Population no 17, pp. 343-363.

Brannen Julia, Lewis Suzanne, Nilsen Ann \& Smithson Janet (2002) Young Europeans, Work and Family. London; New York: Routledge.

Bäck-Wiklund, Margareta \& Bergsten, Birgitta (1997) Det moderna föräldraskapet. En studie av familj och kön $i$ förändring. Stockholm: Natur och kultur.

Early Childhood Education and Care Policy in Sweden. Regeringskansliet, december 1999. 
Erder, Sema (2002) „Urban Migration and Reconstruction of the Kinship of Networks. The Case of Istanbul«. I Rita Liljeström \& Elisabeth Özdalga (eds.) Autonomy and Dependence in the Family. Swedish Research Institute in Istanbul, Transactions Vol.11.

Esping-Andersen, Gösta (1999) Social Foundations of Post-industrial Economies. Oxford, New York: Oxford University Press.

Fagnani Jeanne, Houriet-Ségard Geneviéve \& Bédouin Sébastien (2004) „Gender, parenthood and the changing European Workplace" Transitions Research Report \# 1: Context Mapping for the EU Framework 5 founded study. Printed by the Manchester Metropolitan University: Research Institute for Health and Social Change.

Franshén, Mona \& Bäck-Wiklund, Margareta (2009) "Starting a Family. A comparison between families with Turkish and Swedish background". I Talip Kuckculan Turks in Europe. Culture, Identity and Integration. Amsterdam: Turkey Research Centre.

Fritzell, Johan \& Lennartsson, Carin (2005) „Financial transfers between generations in Sweden". Ageing and Society, No 25, pp. 397-414.

Hirdman, Yvonne (1990) "Genussystemet». I Demokrati och makt I Sverige. Maktutredningens huvudrapport. SOU 1990:44.

Hoem, Britta (2000) "Entry into motherhood in Sweden: the influence of economic factors on the rise and fall in fertility, 1986 - 1997 «. Demographic research vol. 2, art. 4, pub. 17 April 2000. www.demographic-research.org/ Volumes/Vol2/4

Inglehart, Ronald \& Welzel, Christian (2005) Modernization, Cultural Change and Democracy; The Human Development Sequence, New York: Cambridge University Press, 2005. (se www.jacobs-university.de/schools/shss/ cwelzel/07993/)

Kagitcibasi, Cigdem (2002) "Cross-cultural Perspective on Family Change«. I Rita Liljeström \& Elisabeth Özdalga (eds.) Autonomy and Dependence in the Family. Swedish Research Institute in Istanbul, Transactions Vol.11.

Kandiyoti, Deniz (1995) „Patterns of Patriarchy: Notes for an Analysis of Male Dominance in Turkish Society". I Sirin Tekeli (ed.) Women in Modern Turkish Society. London: Zed Books Ltd.

Klint, Roger (2002) Göra pappa med barn; den svenska pappapolitiken. Umeå: Boréa.

Korpi, Walter (2000) "Faces of Inequality: Gender, Class, and Patterns of Inequalities in Different Types of Welfare States». Social Politics. Oxford: Oxford University Press.

Pinnelli Antonella, Hoffman-Nowotny Hans Joakim \& Fux Beat (2001) Fertility and new types of households and family formation in Europe. Council of Europe Publishing, Population Studies no. 35.

Ringen, Stein (1987) The Possibility of Politics. A Study in the Political Economy of the Welfare State. Oxford: Claredon Press.

SCB (2002) Hur många barn fär jag när jag blir stor? Barnafödande ur ett livsperspektiv. Demografiska rapporter 2002:5.

SCB Statistisk Årsbok 1983 till 2003.

Screening Report Turkey Ch 19 Social policy and employment. ec.europa.eu/enlargement/ pdf/turkey/screening_reports/screening_ report_19_tr_internet_en.pdf.

Socialstyrelsen (2000) Olika villkor - olika hälsa. En studie bland invandare frän Chile, Iran, Polen och Turkiet. SoS-rapport 2000:3 Invandrares levnadsvillkor 4 .

Sümer, Sevil (2004) „Family and gender practices of Turkish and Norwegian urban dual earner couples». Sosiologisk tidsskrift Vol. 12, s. 343347.

Therborn, Göran (2004) Between Sex and Power. Family in the world, 1900-2000. New York: Routledge.

www.worldvaluessurvey.org

www.scb.se/befolkning www.prb.org/pdf07/07WPDS_Eng.pdf www.scb.se/templates/tableOrChart_26040.asp

Franséhn, Jansson, Österberg \& Bäck-Wiklund: Familjebildning och försörjning... 


\section{Summary}

\section{Family formation and earnings \\ A comparison of transition to parenthood for new parents with Swedish and Turkish background in a Swedish welfare perspective}

The aim of this article is to analyse how new parents with Swedish and Turkish background adopt to the Swedish dual-earner family model. The study consists of two parts. In the first part we examine whether labour market attachment and social policy affect Turkish-born and Swedish-born women differently concerning the decision to start a family. Using panel data we investigate the impact that labour market attachment, education, and social policy have on Swedish and Turkish women.

The second part of the study is based on interviews using a life-history approach with three different groups who had recently become parents. The groups are young adults with parents born in Sweden or in Turkey or mixed. The aim is to explore why these couples have taken the decision to become parents at this stage of their lives in addition to considerations, experiences and knowledge of importance for their choices. The study focuses on similarities and differences between the three groups as well as individual cases in relation to the Swedish welfare system, notably the support to new parents, and to family traditions in each group based on culture and national background.

The analysis shows that starting a family is much more of an individual life project for the Swedish group of parents. The Swedish social policy and insurance system seem to have an impact on their way of acting. Economy, work and housing conditions are very important for their decision. For the Turkish group starting a family is much more of a collective project related to culture and family traditions. They do not have the same trust in the welfare state but rely more on their own families. The mixed group has more negotiations and conflicts, trying to balance their different views of family life. 